\title{
Intracardiac Pacing as Emergency Treatment in Adams-Stokes Syndrome
}

\author{
GUNNAR BAY,* M.D. ; EGIL SIVERTSSEN,* M.D.
}

Brit. med. F., 1967, 4, 199-200

In most cases of atrioventricular block with Adams-Stokes attacks the application of either an endocardial or an epicardial electrode for artificial pacing can be performed in the operatingtheatre with all necessary equipment available. In some cases, however, the situation is more dramatic: electrical pacing may be necessary without any delay, and it may be impossible to transfer the patient to the operating-theatre or an $x$-ray laboratory with TV equipment. In such emergency cases we have used a technique which renders it possible to introduce an endocardial pacemaker electrode by means of very simple equipment, and the method which we have applied in 27 cases has proved to be safe and reliable. The principle is to use the pacemaker electrode for picking up the electrocardiogram from the heart cavities. As the electrocardiogram from the atrium pacemaking is established. The electric defibrillator and the external pacemaker are held in readiness.

\section{Materials}

From September 1965 to April 1967 indications for intracardiac pacing were found in 62 patients. Twenty-seven of these were critically ill with repetitive Adams-Stokes attacks, and the emergency introduction of an endocardial pacemaker electrode by the described technique was therefore attempted (see Table). Fifteen of these had acute myocardial infarction. In 21 the electrode was successfully placed in the right ventricle, and effective stimulation of the heart was obtained in all of them. In one patient (Case 1) with sinoatrial block the tip

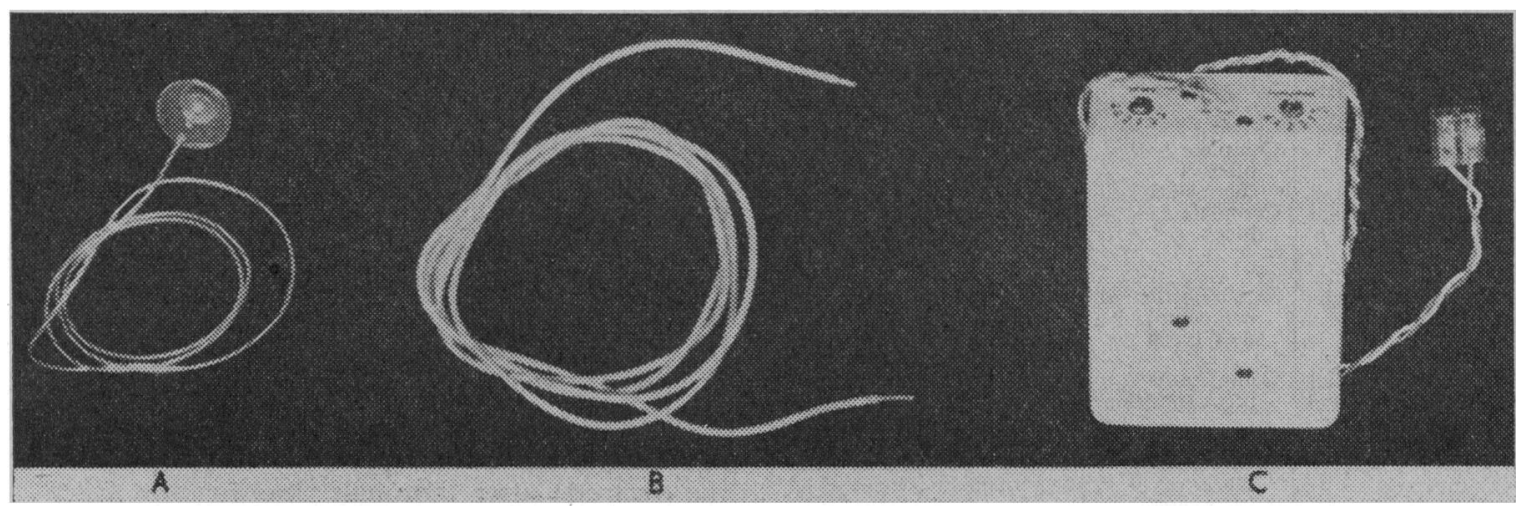

FIG. 1.-A, subcutaneous indifferent electrode. B, soft, flexible intracardiac electrode. C, external pacemaker (ElemaSchönander).

as well as from the ventricle is highly characteristic, the electrocardiographic pattern can easily be used as guide for a correct introduction into the right ventricle without the aid of fluoroscopy.

\section{Method}

Under sterile conditions and after cleansing and draping the area an incision is made over the antecubital or jugular vein. A soft flexible intracardiac electrode (Fig. 1) is introduced into the exposed vein and connected to the $\mathrm{V}$ terminal of an electrocardiograph by means of a clip. The electrode is then advanced to the right atrium under constant monitoring on oscilloscope or electrocardiograph. When characteristic atrial patterns are seen (Fig. 2), the patient is carefully rotated to the left lateral position to facilitate passage of the electrode through the tricuspid valve. The electrocardiographic patterns change suddenly when the electrode passes into the ventricular cavity. The atrial complexes become small, and the ventricular complexes large with the $\mathrm{rS}$ or QS appearance. The electrode is then advanced a further 5-6 cm. to place the tip in the apex region of the right ventricle. At this point typical contact patterns should be seen (Fig. 2). An indifferent electrode is thereafter placed subcutaneously in front of the sternum, and the two electrodes are connected to a battery-driven pacemaker. If the intracardiac electrode is in the correct position, effective stimulation of the heart is gained with an amplitude of 1-2 V.

Intravenous infusion of isoprenaline is started before beginning the procedure, and is continued until satisfactory

* Ullevål Hospital, Department VIII, Oslo. of the electrode did not pass into the ventricle, but effective stimulation was obtained from the right atrium. In one patient with atrioventricular block (Case 4) the typical endoventricular complexes were not registered, but, in spite of this, satisfactory stimulation was obtained. This patient died later in cardiac failure, and at necropsy the tip of the electrode was found in the coronary sinus. In four patients introduction of the electrode was unsuccessful: three (Cases 8, 24, and 25) died during the attempt, the fourth (Case 15) some hours later.
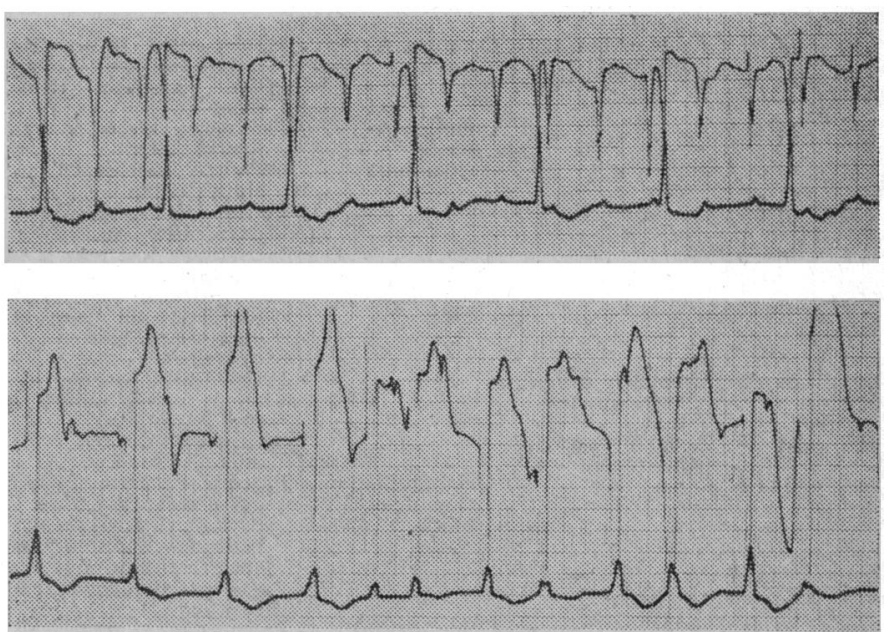

FIG. 2.-Intracavitary E.C.G.-registration during pacemaker electrode placement. Top: Registration from the right atrium and lead I Bottom: Registration from the right ventricle with typical contact patterns. 
Nine of the 21 patients with effective pacing died during the hospital stay: four of them in ventricular fibrillation in spite of satisfactory pacing, and four in cardiac failure. Treatment with artificial pacemaker could be discontinued after 4 to 25 days in five patients in whom sinus rhythm returned. Indica-

\begin{tabular}{|c|c|c|c|c|}
\hline $\begin{array}{l}\text { Case } \\
\text { No. }\end{array}$ & $\begin{array}{l}\text { Sex } \\
\text { and } \\
\text { Age }\end{array}$ & Diagnosis & $\begin{array}{l}\text { Cardiac } \\
\text { Arrhythmias }\end{array}$ & Course \\
\hline 1 & F 48 & $\begin{array}{l}\text { Acute myocardial } \\
\text { infarction }\end{array}$ & Sinoatrial block & $\begin{array}{l}\text { Pacemaker electrode re- } \\
\text { moved after } 4 \text { days. } \\
\text { Patient discharged in } \\
\text { sinus rhythm }\end{array}$ \\
\hline 2 & F 51 & $\begin{array}{l}\text { Chronic poly- } \\
\text { arthritis treated } \\
\text { with chloro- } \\
\text { quine }\end{array}$ & $\begin{array}{l}\text { Complete } \mathrm{A}-\mathrm{V} \\
\text { block (transient) }\end{array}$ & $\begin{array}{l}\text { Pacemaker electrode re- } \\
\text { moved after } 2 \text { days. } \\
\text { Patient discharged in } \\
\text { sinus rhythm }\end{array}$ \\
\hline 3 & M 69 & $\begin{array}{l}\text { Acute myocardial } \\
\text { infarction }\end{array}$ & $\begin{array}{l}\text { Complete A-V } \\
\text { block (transient) }\end{array}$ & $\begin{array}{l}\text { Pacemaker electrode re- } \\
\text { moved after } 14 \text { days. } \\
\text { Patient discharged in } \\
\text { sinus rothm }\end{array}$ \\
\hline 4 & M 66 & . & $\begin{array}{l}\text { Complete } A-V \\
\text { block }\end{array}$ & $\begin{array}{l}\text { Patient died in cardiac } \\
\text { insufficiency in spite of } \\
\text { effective pacemaker }\end{array}$ \\
\hline 5 & M 75 & $\begin{array}{l}\text { Coronary heart } \\
\text { disease }\end{array}$ & $\begin{array}{l}\text { Complete A-V } \\
\text { block (perman- }\end{array}$ & $\begin{array}{l}\text { Patient discharged with } \\
\text { permanent pacemaker }\end{array}$ \\
\hline 6 & F 59 & $\begin{array}{l}\text { Acute myocardial } \\
\text { infarction }\end{array}$ & $\begin{array}{l}\text { Complete A-V } \\
\text { block }\end{array}$ & $\begin{array}{l}\text { Patient died in ventricular } \\
\text { fbrillation in spite of } \\
\text { effective pacemaker } \\
\text { treatment }\end{array}$ \\
\hline 7 & F 74 & $\begin{array}{l}\text { Rheumatic valvu- } \\
\text { lar disease }\end{array}$ & $\begin{array}{l}\text { Atrial fibrillation } \\
\text { and complete } \\
\text { A-V block }\end{array}$ & $\begin{array}{l}\text { Patient discharged with } \\
\text { permanent pacemaker }\end{array}$ \\
\hline 8 & M 68 & $\begin{array}{l}\text { Acute myocardial } \\
\text { infarction. In- } \\
\text { tracerebral }\end{array}$ & $\begin{array}{l}\text { Complete A-V } \\
\text { block }\end{array}$ & $\begin{array}{l}\text { Patient died during at- } \\
\text { tempt to institute pace- } \\
\text { maker treatment }\end{array}$ \\
\hline 9 & M 69 & $\begin{array}{l}\text { bleeding } \\
\text { Coronary heart } \\
\text { disease }\end{array}$ & $\begin{array}{l}\text { Complete A-V } \\
\text { block }\end{array}$ & $\begin{array}{l}\text { Patient discharged with } \\
\text { permanent pacemaker }\end{array}$ \\
\hline 10 & F 75 & $\begin{array}{l}\text { Acute myocardial } \\
\text { infarction }\end{array}$ & $\begin{array}{l}\text { Complete A-V } \\
\text { block }\end{array}$ & $\begin{array}{l}\text { Patient died in ventricular } \\
\text { fibrillation during effec- } \\
\text { tive pacemaker treat- }\end{array}$ \\
\hline 11 & F 67 & $\begin{array}{l}\text { Rheumatic valvu- } \\
\text { lar disease }\end{array}$ & $\begin{array}{l}\text { Atrial fibrillation } \\
\text { and complete } \\
\text { A-V block }\end{array}$ & $\begin{array}{l}\text { Pacemaker electrode re- } \\
\text { moved after } 9 \text { days } \\
\text { Patient died } 14 \text { days later }\end{array}$ \\
\hline 12 & M 57 & $\begin{array}{l}\text { Acute myocardial } \\
\text { infarction }\end{array}$ & $\begin{array}{l}\text { Complete } \mathrm{A}-\mathrm{V} \\
\text { block (transient) }\end{array}$ & $\begin{array}{l}\text { Pacemaker electrode re } \\
\text { moved after } 12 \text { days } \\
\text { Patient discharged in }\end{array}$ \\
\hline 13 & F 67 & $\begin{array}{l}\text { Coronary heart } \\
\text { disease }\end{array}$ & $\begin{array}{l}\text { Complete A-V } \\
\text { block }\end{array}$ & $\begin{array}{l}\text { Patient discharged with } \\
\text { permanent pacemaker }\end{array}$ \\
\hline 14 & F 85 & " $\quad$, & $\begin{array}{c}\text { (permanent) } \\
\quad " \quad "\end{array}$ & Patient discharged with \\
\hline 15 & M 68 & $\begin{array}{l}\text { Rheumatic valvu- } \\
\text { lar disease }\end{array}$ & $\begin{array}{l}\text { Atrial fibrillation. } \\
\text { Repeated attacks } \\
\text { of ventricular } \\
\text { fibrillation }\end{array}$ & $\begin{array}{l}\text { permanent pacemaker } \\
\text { Attempt to institute endo } \\
\text { cardial pacing failed } \\
\text { Patient died some hours } \\
\text { later in ventricular fib } \\
\text { rillation }\end{array}$ \\
\hline 16 & F 72 & $\begin{array}{l}\text { Chronic poly- } \\
\text { arthritis treated } \\
\text { with chloroguine }\end{array}$ & $\begin{array}{l}\text { Complete A-V } \\
\text { block } \\
\text { (intermittent) }\end{array}$ & $\begin{array}{l}\text { Patient discharged with } \\
\text { permanent pacemaker }\end{array}$ \\
\hline 17 & F 69 & $\begin{array}{l}\text { Acute myocardial } \\
\text { infarction }\end{array}$ & $\begin{array}{l}\text { Complete A-V } \\
\text { block }\end{array}$ & $\begin{array}{l}\text { Patient died in cardiac } \\
\text { failure in spite of effec } \\
\text { tive pacemaker treat }\end{array}$ \\
\hline 18 & F 61 & $\begin{array}{l}\text { Rheumatic valvu- } \\
\text { lar disease }\end{array}$ & Complete A-V & $\begin{array}{l}\text { Patient discharged with } \\
\text { permanent pacemaker }\end{array}$ \\
\hline 19 & F 67 & $\begin{array}{l}\text { Chronic poly- } \\
\text { arthritis treated } \\
\text { with chloro- } \\
\text { auine }\end{array}$ & $\begin{array}{l}\text { (permanent) } \\
\text { Complete A-V } \\
\text { block } \\
\text { (intermittent) }\end{array}$ & $\begin{array}{l}\text { Patient discharged with } \\
\text { permanent pacemaker }\end{array}$ \\
\hline 20 & M 71 & $\begin{array}{l}\text { Acute myocardial } \\
\text { infarction }\end{array}$ & $\begin{array}{l}\text { Complete } \mathrm{A}-\mathrm{V} \\
\text { block }\end{array}$ & $\begin{array}{l}\text { Patient died in cardiac } \\
\text { failure in spite of effec } \\
\text { tive pacemaker treat }\end{array}$ \\
\hline 21 & M 53 & & $\begin{array}{l}\text { Complete A-V } \\
\text { block } \\
\text { (transient) }\end{array}$ & $\begin{array}{l}\text { Pacemaker electrode re } \\
\text { moved after } 25 \text { days } \\
\text { Patient discharged in } \\
\text { sinus rhythm }\end{array}$ \\
\hline 22 & M 53 & & & $\begin{array}{l}\text { Patient died suddenly } 7 \\
\text { days after pacemaker } \\
\text { treatment had been dis- } \\
\text { continued }\end{array}$ \\
\hline 23 & F 70 & & $\begin{array}{l}\text { Complete } \mathrm{A}-\mathrm{V} \\
\text { block }\end{array}$ & $\begin{array}{l}\text { Patient died in ventricular } \\
\text { fibrillation in spite of } \\
\text { effective pacemaker } \\
\text { treatment }\end{array}$ \\
\hline 24 & M 48 & $\begin{array}{l}\text { Unknown aetio- } \\
\text { logy. intoxica- } \\
\text { tion }\end{array}$ & & $\begin{array}{l}\text { Patient died during at- } \\
\text { tempt to institute pace- } \\
\text { maker treatment }\end{array}$ \\
\hline 25 & M 55 & $\begin{array}{l}\text { Acute myocardial } \\
\text { infarction }\end{array}$ & , $\quad$ " & $\begin{array}{l}\text { Patient died during } \\
\text { attempt }\end{array}$ \\
\hline 26 & F 67 & " " & $\begin{array}{l}\text { Atrial fibrillation. } \\
\text { Complete A-V } \\
\text { block }\end{array}$ & $\begin{array}{l}\text { Pacemaker electrode pulled } \\
\text { out accidentally after } 4 \\
\text { days, but heart rate and } \\
\text { patient's condition was } \\
\text { such that reintroduction } \\
\text { was not thought neces- } \\
\text { sary }\end{array}$ \\
\hline 27 & F 56 & & $\begin{array}{l}\text { Complete A-V } \\
\text { block }\end{array}$ & $\begin{array}{l}\text { Patient died in ventricular } \\
\text { fibrillation in spite of } \\
\text { effective pacemaker } \\
\text { treatment }\end{array}$ \\
\hline
\end{tabular}

tions for permanent pacemaker treatment were present in eight patients.

\section{Discussion}

Intracavitary electrocardiography has for many years been used in cardiac catheterization to determine the location of the catheter tip. The method has also been used in the daily clinical work as a supplementary method in the diagnosis of cardiac arrhythmias, utilizing a thin Teflon-coated stainlesssteel wire with a platinum tip (Vogel et al., 1964 ; Nutter and Kelser, 1965 ; Sivertssen, 1967). This electrode has been used for temporary pacing of the heart (Harris et al., 1965 ; Kimball and Killip, 1965).

Introduction of the intracardiac pacemaker electrode should preferably be performed under fluoroscopy and TV monitoring. In urgent situations when such equipment is not available, the described method can be used as a bedside procedure. The technique is easy to perform, may be applied quickly, and does not require other special equipment than that usually available in most medical departments. The identification of the intracardiac electrocardiographic patterns is not too difficult in most cases, but extremely slow heart rates may cause a problem because so few ventricular patterns are seen. It is extremely important to make sure that the recorder and other instruments connected to the patient are properly earthed. Leaking of electric current through the intracavitary electrode may provoke ventricular fibrillation.

The electrode may be introduced in the vein percutaneously in patients with large antecubital or jugular veins. In most cases, however, a cut down on the vein is necessary. We have tried thin Teflon-coated steel-wire electrodes designed for intracavitary electrocardiographic diagnosis, but have not obtained effective stimulation. It is of great importance that the electrode is soft and flexible because of the danger of perforating the ventricular wall during the introduction.

In eight patients artificial pacemaking had to be continued as a permanent treatment. In these cases the external end of the electrode after thorough cleansing was taken out through an incision in the subclavian vein and then led subcutaneously to the right abdominal region, where it was attached to an implanted pacemaker. Infection or thromboembolic complications have not occurred. In most cases the electrode was introduced into an antecubital vein, usually the basilic vein of the right arm. When the electrode was firmly fixed in the elbow region, the patient was able to move the arm freely without displacement of the electrode. In one patient the electrode was pulled out accidentally during sleep. Usually the external jugular vein is used for introduction of pacemaker electrodes for permanent treatment. In urgent situations, however, it may be difficult to find a suitable vein in the neck.

The intracardiac electrode has been removed without difficulty even after 25 days, when further treatment with the artificial pacemaker was not indicated.

\section{Summary}

A simple and effective bedside method is presented for transvenous intracardiac pacing in urgent clinical situations when fluoroscopic equipment is not available. The method permits intracardiac electrode placement using the intracavitary electrocardiogram picked up by the pacemaker electrode as a guide.

Successful placement of the electrode was achieved by this method in 21 out of 27 critically ill patients with repetitive Adams-Stokes attacks.

\section{REPERENCES}

Harris, C. W., Hurlburt, J. C., Floyd, W. L., and Orgain, B. S. (1965). Amer. .." Cardiol. $15,48$.

Kimball, J. T., and Killip, T. (1965). Amer. Heart Y., 70, 35.

Nutter, D. O., and Kelser, G. A., jun. (1965). Ann. interm. Med., 62 706.

Sivertssen, E. (1967). Acta med. scand., 181, 55

Vogel, J. H. K., Kambuzia, T., Averill, K. H., and Blount, S. Gilben (1964). Amer. Heart Y., 67, 158. 